\section{IUFRO Conference on Rusts of Pine}

The International Union of Forest Research Organizations and the Canadian Forestry Service will sponsor a meeting on rusts of pine at the Banff Centre, Banff, Alberta on September 18-22, 1989. Topics covered will include: (1) Taxonomy, life cycle and distribution; (2) Host-parasite interaction; (3) Epidemiology; (4) Resist- ance testing and screening methods; (5) Interaction with mycoparasites, insects and animals; (6) Hazard rating, impact assessment and loss estimates; (7) Management and control; and (8) Research collaboration and networking.

For information and registration forms, contact Dr. Yasu Hiratsuka, Northern Forestry Centre, Canadian Forestry Service, 5320-122nd Street, Edmonton, Alberta T6H 3S5, Canada.

\section{Commonwealth Forestry Conference}

The Conference will be held at Rotarua, New Zealand, September 18-29, 1989. The tentative title is "Forestry as a Multiple Use Enterprise." There will be a post conference tour to South Island, New Zealand. A further notice will appear about this conference.

\title{
RPF News/Nouvelles des ingénieurs forestiers
}

\author{
Ordre des ingénieurs forestiers du Québec
}

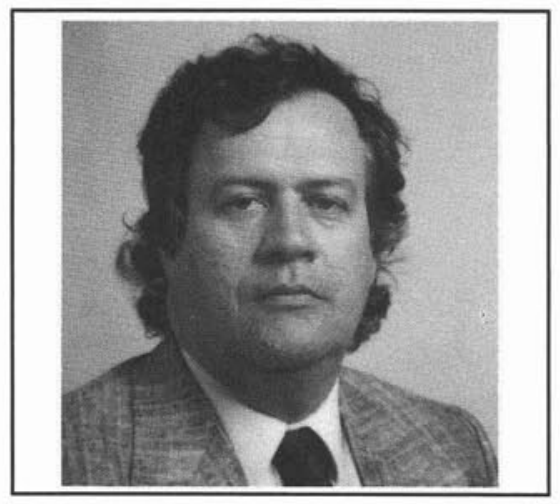

Les membres du Bureau de l'Ordre des ingénieurs forestiers du Québec ont récemment élu à la présidence de leur organisme M. Carl Charbonneau, ing.f., M.Sc. directeur du Centre d'enseignement et de recherche en foresterie de SainteFoy, inc. (C.E.R.F.O.).

Les autres membres du comité administratif sont: au poste de vice-président, $M$. Germain Paré, ing.f., M.Sc., responsable de la division recherche en gestion des forêts au ministère de l'Energie et des Ressources du Québec; au poste de trésorier, M. Jean Tomlinson, ing.f., M.Sc., professeur agrégé en sciences forestières à l'Université Laval' au poste d'administrateur, M. Pierre $Y$. Bourdages, ing.f., M.B.A., directeur général de l'administration, Matériaux de construction Domtar, Montréal; au poste d'administratrice représentant le public, Mme Lucie Bigué, M.urb., adjointe administrative au directeur général de la Société d'habitation du Québec.

L'Ordre des ingénieurs forestiers du Québec est l'organisme qui régit la pratique professionnelle de quelque 1650 ingénieurs forestiers exerçant au Québec et à l'étranger.

\section{Journal Bargains for Institute Members!}

The Table of Contents of the Canadian Journal of Forest Research is carried every month in The Forestry Chronicle. Members are reminded that this prestigious forest research publication is available to them at a very special price of $\$ 26.00$ per year. The normal rate for Canadian individual subscribers for this Journal, direct from NRC is $\$ 52.00$. Here then is another advantage of membership - a saving of $50 \%$ on the price of a subscription to Canadian Journal of Forest Research. Indeed, all NRC Journals are available to CIF Members at greatly reduced prices. Not for all members to be sure but a real saving for some.

Send your order and cheque to National Office.

\section{Retired Members}

This note is to remind retired members and Section Councils about the provisions of By Law 4.4 which allows individuals who have been Institute members for 15 or more years and who retire "with a substantial reduction in income" to apply for retired status. If approved, retired status members are not required to pay any dues, but retain all rights and benefits except receipt of The Forestry Chronicle. The Chronicle for 1988 is available to retired members on payment of $\$ 29.00$, but dues are for the period July 1,1987 to June 30,1988 .

The proper procedure for those interested in this provision is to apply to your Section Council. Councils will deal with these applications and notify National Office of the decision so that records can be adjusted. 